\title{
The Effect Of Technological Pedagogical Content Knowledge (Tpack) On The Geographic Skills Of Bandung City Senior High School Students
}

\author{
Adella Ramadhani Kusuma Putri ${ }^{1}$, Epon Ningrum ${ }^{2}$, Ahmad Yani ${ }^{3}$ \\ \{ $\underline{\text { adellarkputri@upi.edu }^{1}}, \underline{\text { eponningrum@upi.edu }}{ }^{2}, \underline{\text { ahmadyani@upi.edu }^{3}}$ \}
}

Graduate School of Geography Education Study Program, Indonesia University of Education ${ }^{123}$

\begin{abstract}
The Education is a means to increase the level of human resources; education itself cannot be separated from the role of the teacher as the spearhead to carry out teaching activities. The teacher himself is a significant factor in determining the success or failure of the teaching activity, primarily to determine whether students get the essence of the learning carried out or vice versa. Application of Technological Pedagogical and Content Knowledge (TPACK) is knowledge about facilitating student learning of specific content through an academic approach and technology. TPACK is the knowledge needed so that a prospective physics teacher can use the right technology, which is based on an analysis of the character of the material and an analysis of the pedagogical aspect. TPACK can improve students' skills to enhance geography skills acquired in the learning process based on research. Hence, TPACK is an essential supporting factor in determining whether or not students' geography skills are good. The population in this study was 105 teachers who teach geography in Bandung City Senior High School, using a random sampling technique. The analysis of hypothesis testing that has been carried out results in the finding that TPACK has a positive and significant effect on students' geography skills. These findings can be interpreted that the application of TPACK can improve students' geography skills in the learning process carried out on high school students in the city of Bandung.
\end{abstract}

Keywords: Technological Pedagogical an

\section{Introduction}

Geographic thinking competence, especially among formal people who receive geography education, namely students, needs to be carried out and research. The study results will be beneficial for mapping geographical thinking skills among students and are expected to be used as a database for policy formulation, especially geography education policies concerning curriculum and teacher competency standardization. There are four thinking skills (Krulik and Rudnick, 1999, pp. 138-145), namely recall thinking, essential thinking, critical thinking, and creative thinking. Based on the Pedagogical Content Knowledge framework by Shulman (1986, p. 9), TPACK is considered to have a role in advancing the quality of education and knowing the implications of TPACK in the world of education.

Technological Pedagogical and Content Knowledge (TPACK) is knowledge about facilitating student learning of specific content through pedagogic approaches and technology (Mishra and Koehler, 2006; Cox \& Graham, 2009; Harris, 2009). TPACK is a complex form of knowledge and is very important for teachers. TPACK is the knowledge needed so that a prospective physics teacher can use the right technology, which is based on an analysis of the character of the material and an analysis of the pedagogical aspect (Mishra and Koehler, 2006). TPACK requires unique multiinteractions and synergies between materials, pedagogy, and technology (Mishra et al., 2008). 


\section{Literature Review}

TPACK is a framework that integrates technological knowledge (Technological Knowledge), pedagogical knowledge (Pedagogy Knowledge), and content knowledge (Content Knowledge) in a learning context (Ariyana, 2018). Content knowledge (Content Knowledge $=\mathrm{CK}$ ), pedagogical knowledge (Pedagogical knowledge $=\mathrm{PK}$ ), and technological knowledge (Technological knowledge $=\mathrm{TK}$ ) in a TPACK framework each have complex interactions. TPACK) (Nurdiani, 2019).

Assessing the TPACK of a teacher in designing learning with technology, an instrument has been developed that includes five indicators (Nurdiani, 2019), namely:

1. Topics to be taught with the help of technology must be identified first, which issues are challenging and easy to teach effectively in class.

2. For learning to be understood by students, teachers must identify which content is challenging to support in traditional ways.

3. Identify teaching strategies that are difficult to implement in traditional ways.

4. Use effective teaching strategies and be able to choose the right computer equipment.

5. Able to combine selected technologies that make learning

The study of geography also provides opportunities for learners to develop their general intellectual skills for lifelong learning and general skills such as critical thinking, communication, information processing, problem-solving, decision making, etc. (Bulter, 2013 p.19). Such concepts and skills are combined in geography for life: National Geographic Content Standards (1994), with an updated 2nd edition released in 2010. Studying the spatial relationships between human and physical systems components is enhanced by using the latest geographic information and the most reliable technology available. Opportunities for students and geographers to observe, synthesize, and present areas and utilize geographic information such as potential areas in the spread of disease, identify market areas, production centers, centers of economic growth, and so on.

In the context of the curriculum, it is known as the geographic approach (Parjito, 2015 p. 248). There are five geography skills, which are intended by the book, namely:

1. Skills in asking geographic questions (asking geographic questions).

2. Skills in obtaining geographic information, visible skills in getting geographic information including finding and collecting data, observing and systematically recording information, reading and interpreting maps and other graphical representations of space and place, interviewing, and using methods statistics.

3. Skills in managing or organizing geographic information.

4. To analyze geographic information, students must examine maps to find and compare spatial patterns and relationships.

5. Ability to answer geographic questions (answering geographic questions).

6. The ability to communicate or inform geographic data (sharing geographic information), that is, students must also understand that there are alternative ways to reach generalizations and conclusions.

\section{Results and Discussion}

The research method used in this research is to use two research methods, namely descriptive and verification methods. According to Sugiyono (2017:35), verification research is a study aimed at testing theories. The research will try to produce new scientific information, namely the status of the hypothesis in the form of a conclusion, whether an idea is accepted or rejected. The verificative analysis is used in this study to identify and examine the third problem formulation, namely, how much influence the geography teacher's understanding of TPACK has on the students' geography skills.

Tabel 1. Operational Variable

\begin{tabular}{|l|l|l|}
\hline No & Variable & Indicator \\
\hline
\end{tabular}




\begin{tabular}{|c|c|c|c|}
\hline 1 & $\begin{array}{l}\text { Technological Pedagogical Content } \\
\text { Knowledge (TPACK) } \\
\text { (Puspitarini, 2013, hlm. 3) }\end{array}$ & $\begin{array}{l}\text { 3) } \\
\text { 4) } \\
\text { 5) }\end{array}$ & $\begin{array}{l}\text { Topics to be taught with the help of } \\
\text { technology must be identified first, } \\
\text { which issues are challenging and easy } \\
\text { to teach effectively in class. } \\
\text { For learning to be understood by } \\
\text { students, teachers must identify which } \\
\text { content is challenging to support in } \\
\text { traditional ways. } \\
\text { Identify teaching strategies that are } \\
\text { difficult to implement in traditional } \\
\text { ways. } \\
\text { Use effective teaching strategies and } \\
\text { be able to choose the right computer } \\
\text { equipment. } \\
\text { Able to combine selected technologies } \\
\text { that make learning }\end{array}$ \\
\hline 2 & $\begin{array}{l}\text { Keterampilan Geografi } \\
\text { (Irawan, 2019, hlm. 46) }\end{array}$ & $\begin{array}{l}\text { 1) } \\
\text { 2) } \\
\text { 3) } \\
\text { 5) } \\
\text { 6) }\end{array}$ & $\begin{array}{l}\text { Students' skills in identifying } \\
\text { problems Asking geography questions } \\
\text { Students can collect data, including } \\
\text { observations and measurements of } \\
\text { geographical phenomena phenomena } \\
\text { Students can organize and process } \\
\text { geographic data data } \\
\text { Analyze geographic information to } \\
\text { answer questions } \\
\text { Answering geography questions or } \\
\text { solving problems } \\
\text { Ability to communicate geographic } \\
\text { data to friends }\end{array}$ \\
\hline
\end{tabular}

Researchers used the solving method to determine the number of samples to be studied. The method of determining the sample size using the solving method is as follows:

Where :

$$
n=\frac{N}{1+N e^{2}}
$$

$\mathrm{n}=$ Sample size

$\mathrm{N}=$ Population size

$e^{2}=$ Error tolerance limit (error tolerance)

Population $n=142$ assuming the error rate $(e)=5 \%$, then the number of samples that must be used in this study isk

$$
n=\frac{142}{1+\mathbf{1 4 2}(0,5)^{2}}=104,78 \sim 105
$$

Based on the calculation above, it can be obtained the size (n) in this study as many as 105 people will be used as the sample size in the study.

\section{Hypothesis Testing}

The hypothesis test referred to in this study is to determine whether or not there is an influence on the geography teacher's understanding of TPACK on the students' geography skills. The hypothesis test for this correlation is formulated with the null hypothesis $\left(\mathrm{H}_{0}\right)$, and the alternative hypothesis (H1), the formula for the idea is as follows:

Simultaneous hypothesis testing or F test is used to determine the effect of all independent variables on the dependent variable. The F statistical test shows whether all the independent variables included in the model have a combined effect on the dependent variable. The hypothesis put forward can be described as follows: 
H0 There is no effect of understanding the geography teacher's TPACK on students' geography skills in Bandung City High School.

H1 There is an influence on understanding the geography teacher's TPACK on students' geography skills at SMA Bandung City.

Based on these calculations, the distribution of $F$ will be obtained with the numerator $(K)$ and the denominator (n-k-1) with the following conditions:

If Fcount > Ftable, then Ho is rejected, and vice versa, $\mathrm{H} 1$ is accepted.

If Fcount < Ftable, then Ho is accepted, and vice versa, $\mathrm{H} 1$ is rejected.

\section{Conclusion}

Based on descriptive analysis, the TPACK variable has an average total in the range of 2.60-3.40, so it can be seen that the TPACK variable is in the poor category, or it can be interpreted that the TPACK framework applied by geography teachers in Bandung City is still in the poor class. In unfavorable conditions, the application of the framework has not been maximally used to learning. Based on the descriptive analysis of the geography skills variable having a total average in the range of 2.60-3.40, it can be seen that the geography skill variable is in the poor category, or it can be interpreted that the geography skills of students in the city of Bandung do not understand and can apply learning that has been given to the way of thinking about geography as a whole and in detail so that students' understanding is more in general terms and is less able to analyze geographic data further. The results of hypothesis testing that have been carried out can be seen that the TPACK framework has a significant and significant effect on students' geography skills in Bandung. This can be interpreted that the TPACK framework used by the teacher in teaching can affect the results of the geography skills of the students taught by the teacher, this condition can mean that if the teacher's TPACK framework is good, the student's geographic skills can give good results and vice versa. Based on the calculation of the coefficient of determination, the TPACK framework's influence is $35 \%$ on students' geography skills. It can be said that with this percentage, the TPACK's influence on students' geography skills.

\section{References}

Cox, S., \& Graham, C. R. (2009). "Diagramming TPACK in practice: using an elaborated model of the TPACK framework to analyze and depict teacher knowledge." TechTrends, 53(5), 60-69.

Harris, J., Mishra, P., \& Koehler, M. (2009). Teachers' Technological Pedagogical Content Knowledge And Learning Activity Types: Curriculum-Based Technology Integration Reframed. Journal Of Research On Technology In Education, 41(4), 393-416.

Kemp, J.E. dan Dayton D.K. 1985. "Planning and Producing Instructional Media." Cambridge: Harper \& Row Publishers, New York.

Krulik, Stephen dan Rudnick, Jesse A. 1999. Innovative Task To Improve Critical and Creative Thinking Skills. Reston: The National Council of Teachers of Mathematics, Inc.

Kurt F. Et al. 2013. Internal Auditing: Assurance \& Advisory Services Third Edition. Florida: The Institute of Internal Auditors Research Foundation (IAAF).

Maryani, E. (2006). Pendidikan Geografi, dalam Ilmu dan Aplikasi Pendidikan. Karangan Mohammad Ali, dkk. Bandung: Pedagogiana Press.

Maryani, Enok. (2011). Pengembangan program Pembelajaran IPS Untuk Peningkatan Keterampilan Sosial. Bandung: Alfabeta.

Masoka, M., Ibrohim., \& Indriwati, S. E. (2017).Studi eksplorasi kualifikasi dan kompetensi guru bidang studi biologi SMP-SMA sebagai basis program peningkatan kualitas pendidikan. Jurnal Pendidikan, 2(4), 516-523.

Mishra, P., \& Koehler, M. J. (2006). Technological Pedagogical Content Knowledge: A Framework For Teacher Knowledge. Teachers College Record, 108(6), 1017-1054. 
Mukminan, 2014. Peningkatan Kualitas Pembelajaran Pendayagunaan Teknologi Pendidikan. Makalah Seminar Nasional Teknologi Pendidikan: Universitas Negeri Surabaya.

Nurdiani, N. (2019). Kerangka Kerja Technological Pedagogical and Content Knowledge (TPACK) dan Implementasinya Pada Perkuliahan Embriologi.

Nurdiansyah dan Eni. (2016). Inovasi Model Pembelajaran Sesuai Kurikulum 2013). Sidoarjo: Nizamia Learning Center.

Nurhayati, S. (2019). Analisis Berpikir Kreatif Pada Penerapan Problem Based Learning Berpendekatan Science, Technology, Engineering, and Mathematics. Jurnal Inovasi Pendidikan Kimia, 13(1), 2307-2317.

Purwaningsih, E., Nur, M., \& Wasis. 2015. The TPACK Model of Prospective Physics Teacher in Universitas Negeri Malang. Proceedings International Conference on Mathematics, Sciences, and Education, University of Mataram 2015.

Ruhimat, Toto. (2013). Kurikulum \& Pembelajaran. Jakarta: Rajawali Pers.

Shulman, L.S.(1998). Knowledge and Teaching: Foundation of The New Reform. Harvard Educational Review.

Sugiyono. (2017). Metode Penelitian Kuantitatif, Kualitatif, dan R\&D. Bandung : Alfabeta, CV 